Working Paper 9411

\title{
SIMILARITIES AND DISSIMILARITIES \\ IN THE COLLAPSES OF THREE STATE- CHARTERED PRIVATE DEPOSIT INSURANCE FUNDS
}

by Walker F. Todd

Walker F. Todd, an attorney at the law firm of Buckingham, Doolittle, and Burroughs, Cleveland, is a former assistant general counsel and research officer at the Federal Reserve Bank of Cleveland. For helpful comments, the author thanks Tess Ferg, James B. Thomson, Jack McCarthy, and Richard E. Randall. A related article by the author was published as "Lessons from the Collapse of Three State-Chartered Private Deposit Insurance Funds," Federal Reserve Bank of Cleveland, Economic Commentary, May 1, 1994.

Working papers of the Federal Reserve Bank of Cleveland are preliminary materials circulated to stimulate discussion and critical comment. The views stated herein are those of the author and not necessarily those of the Federal Reserve Bank of Cleveland or of the Board of Governors of the Federal Reserve System.

October 1994 


\begin{abstract}
The January 1991 collapse of the Rhode Island Share and Deposit Indemnity Corporation (RISDIC) was the last in a series of two-decades-long collapses of statechartered, privately operated deposit insurance funds for thrift institutions. This paper analyzes the collapse of RISDIC with a view toward distinguishing the elements of failure it shared with the 1985 collapses of the Ohio and Maryland funds.

It took Rhode Island officials nearly three years to return the full amount of principal to depositors at five RISDIC-insured credit unions, and about two-thirds of all RISDIC-insured deposits were frozen for the greater part of a year. However, the state lobbied successfully for a $\$ 180$ million federal loan guarantee for a bond issue, with the proceeds used to provide liquidity to frozen RISDIC-insured deposits. Moreover, during 1993 , a final charge of $\$ 31.9$ million was used for defeasance of the remaining liability for the federally guaranteed bond issue.

The Rhode Island solution was more protracted than in Ohio, where a "cold turkey"/no federal assistance approach was followed, but was less protracted than in Maryland, which minimized federal involvement but used withdrawal limitations to avoid the immediate pain of a total closing of the affected privately insured institutions. Although Rhode Island taxpayers still confront a RISDIC-derived insurance fund shortfall in excess of $\$ 350$ million (mid-1993 estimate), they have the capacity to achieve an entirely state-funded solution over the long term, a praiseworthy accomplishment for a state with only 1 million people.

The Rhode Island fund and the other state funds studied suffered from common defects that have plagued private deposit insurance schemes in the past, such as dominance of the legislature by the private fund and incapacity of the fund's supervisors to rein in the risk-taking activities of the largest insured institutions. The existence of these defects in the examples studied does not necessarily mean that all private deposit insurance funds are doomed to fail. However, it probably does mean that private deposit insurers have to exercise greater vigilance than in the past if future RISDIC-like failures are to be avoided.
\end{abstract}




\section{Introduction}

The January 1991 collapse of the Rhode Island Share and Deposit Indemnity Corporation (RISDIC) was the last in a series of post-1970 failures of state-chartered, privately operated deposit insurance funds for thrift institutions, industrial banks, and some credit unions. The failures began in Mississippi in 1976 and continued in Nebraska and California (1983), Ohio and Maryland (1985), Utah and Colorado (1987), and Rhode Island (1991). By February 1989, even the Federal Savings and Loan Insurance Corporation's (FSLIC) authority to accept new conservatorships or receiverships was effectively suspended. The Resolution Trust Corporation was created the following August to administer the resolution of insolvent thrifts whose deposits were FSLIC insured, and the FSLIC was abolished (Kane [1992]; U.S. House of Representatives [1985]).

This paper analyzes the collapse of RISDIC with a view toward distinguishing the elements of failure that it shared with other large state-chartered deposit insurance funds -principally the Ohio and Maryland funds -- from those that were unique to Rhode Island. The principal factor separating the solutions that state and federal officials decided upon in Rhode Island from the solutions used in Ohio and Maryland were a congressional field hearing in Rhode Island and a federal loan guarantee for part of the bonds issued by the Depositors Economic Protection Corporation (DEPCO). DEPCO is the state-chartered entity whose bond issues funded the liquidations of the remaining RISDIC-insured institutions and provided some liquidity to the frozen claims of depositors in RISDIC-insured institutions (U.S. House of Representatives [1991]). Federal Reserve Banks' discount window advances, which were a principal source of depositors' liquidity in Maryland and, to a small degree, in Ohio, were not 
a factor in Rhode Island. However, officials of the Boston Fed were prepared to make advances in Rhode Island if an appropriate occasion arose (Preston [1986]; Syron [1991]).

Despite the comparative success of Rhode Island in providing a fair measure of relief over time for claimants whose RISDIC-insured deposits were frozen, problems remain. Nearly three years passed after the RISDIC-insured institutions were closed before depositors at five of them received full reimbursement of their principal on October 15, 1993, as did depositors of another institution engaged in a court-supervised self-liquidation who wished to obtain the DEPCO-funded return of their funds. Besides providing liquidity for those six institutions, DEPCO still is administering at least a small part of the assets remaining from six additional institutions sold or merged into federally insured depositories with DEPCO assistance (McCarthy [1994]). After setting aside $\$ 31.9$ million for complete defeasance of the $\$ 180$ million federally guaranteed bond issue of 1991 during fiscal year 1993, DEPCO's current unfunded deficit has been reduced to about $\$ 356$ million as of June 30, 1993, a huge burden in a state with a population of only 1 million and with pre-crisis operating budgets of about $\$ 1.5$ billion per year (DEPCO [1993]). An alternative suggestion for resolution of the crisis is presented in the conclusion of this paper, and the appendix to the paper analyzes the sources and uses of funds for RISDIC's liquidation.

\section{Background}

Federal deposit insurance did not exist until 1933 (see Flood [1992]), but several states introduced private deposit insurance schemes in the early part of this century. By 1933, however, all the state plans had failed (Wheelock and Wilson [1994]; Todd and O'Driscoll 
[1993]). In the 1950s, interest in private deposit insurance was revived: Ohio enacted its private deposit guaranty association law, covering building and loan and savings and loan associations (S\&Ls), in 1955, and Maryland enacted its private deposit insurance law for S\&Ls in 1962. RISDIC was chartered in 1969 and commenced business in 1971 with 40 member credit unions and insured share accounts of \$134 million. ${ }^{1}$

During the late 1970 s and early 1980 s, a secular rise in interest rates adversely affected the profitability of many thrift institutions, and their loan and investment powers were expanded without a proportionate increase in the accuracy of accounting rules or in effective supervision. These factors eventually brought to light net worth crises in both the federal and state-chartered thrift institution deposit insurance systems (Kane [1989; 1992]). Such problems, sometimes exacerbated by fraud, first overwhelmed the smaller state-chartered deposit insurance funds (Mississippi, Nebraska, and a small California fund for "thrifts and loans"), and then affected the largest state-chartered funds (Ohio and Maryland) by 1985. The FSLIC itself is now generally recognized to have been effectively insolvent on a market-value accounting basis by 1980 , even though that insolvency was not publicly acknowledged by the responsible officials until the late $1980 \mathrm{s.}^{2}$

Officials in charge of most of the remaining large state-chartered private deposit insurance funds took steps after the Maryland collapse in May 1985 to prevent similar problems in their states. In Massachusetts, North Carolina, and Pennsylvania, for example, the comparable deposit insurance funds generally urged their members who could qualify to apply for federal deposit insurance as soon as possible. They remained in business only as backup insurers for deposits in excess of the $\$ 100,000$ federal limit (the Massachusetts model) 
or for institutions too small to qualify for federal deposit insurance (typically, those with less than $\$ 5$ million of total deposits)(see Kane [1992]).

Rhode Island officials, on the other hand, deliberately chose to defy the disturbing signs from Ohio and Maryland and even raised RISDIC's insured deposit limit to $\$ 500,000$ (with unlimited coverage on certain accounts) in late 1985. Despite explicit warnings from the Rhode Island attorney general and a bill filed in the legislature in 1986 to require federal deposit insurance for qualifying RISDIC institutions, no plan for the orderly winding up of RISDIC's affairs was implemented. The 1986 bill failed and was not reintroduced in later years (Pulkkinen and Rosengren [1993]; Gregorian [1991]).

Also, adverse trends regarding the solvency of the largest RISDIC member, Marquette Credit Union (closed in 1991), were noted in the outside auditor's report on RISDIC as early as 1981. Marquette had $\$ 339$ million of total assets at book value when it was closed in January 1991 and held about one-fifth of all deposits insured by RISDIC. ${ }^{3}$ When the outside auditors began to qualify their financial reports, RISDIC changed audit firms and received "clean" opinion letters (qualified only in footnotes to the financial statements) through $1988 .^{4}$ However, the emergence of problems at specific institutions could easily have escaped the notice of RISDIC's board of directors, who apparently did not review examiners' reports and who had no audit committee analyzing the work of RISDIC's outside audit firm (Gregorian [1991]). The RISDIC board shared one significant trait with the failed Maryland insurance fund: A large majority (15) of its members were representatives of the insured institutions, and only three directors were appointed to represent the public interest. In Maryland, the insured institutions appointed eight of the 11 directors (ibid. and Preston [1986]). 
Prominent Rhode Island political figures held important positions in RISDIC-insured institutions and may have used their legislative influence both to fend off reform proposals like the 1986 bill to require federal deposit insurance and to help RISDIC stall for time as its rate of collapse accelerated during $1990 .^{5}$ The chairman of the Rhode Island Credit Union League, which operated as a trade association for the state-chartered credit unions, also served as vice chairman of the State Assembly's committee with jurisdiction over credit unions, and the committee's chairman served as an officer in one of the three largest RISDIC-insured credit unions. The effects of this politicization are summarized as follows in the conclusion of the report of the governor's special study commission on the collapse of RISDIC:

Collectively and individually, RISDIC staff and directors lacked insurance experience, had little banking experience outside of the small world of Rhode Island state-chartered financial institutions, and possessed modest educational and professional credentials. Nevertheless, they were well compensated and had great confidence in each other's talents and integrity. RISDIC directors seemed generally oblivious to the complex risks for which they were responsible. Examination findings and problems noted at member institutions were filtered out or excused as they were communicated upward within RISDIC. The result was an uninformed board. (Gregorian [1991])

\section{A Chronology of the Events Leading to RISDIC's Demise}

The precipitating factors in RISDIC's collapse were two failures of insured institutions during 1990 that essentially depleted the funds available to RISDIC and precipitated runs on other insured institutions in November and December of that year. Those runs prompted Governor Sundlun to order all RISDIC-insured institutions closed as his first significant act upon assuming office on January 1, 1991. At the end of February 1990, Jefferson Loan and Investment Bank (not a credit union) was discovered to have borrowed its capital from another financial institution in violation of state regulations, to have recorded equipment lease income 
improperly, and to have paid exorbitant management fees to its parent holding company. RISDIC took control of Jefferson and reserved \$3.9 million to cover Jefferson's losses, but did not propose a new assessment of RISDIC's member institutions then (Gregorian [1991]).

The second failure that precipitated the end of RISDIC was attributed to loan defalcations at Heritage Loan and Investment Company (also not a credit union) discovered during the third quarter of 1990 . The loan losses caused RISDIC to infuse $\$ 17.5$ million into Heritage in October and November 1990 and to assess RISDIC member institutions a further $\$ 5.5$ million to maintain RISDIC's reserve level. The president of Heritage also was a director of RISDIC. On November 8, 1990, he disappeared (two years later, he reappeared, was arrested, tried, convicted, and currently is in prison). News of his disappearance caused a public run on Heritage, and the state's Treasurer and some other RISDIC-insured institutions also withdrew their deposits (ibid. and Ingrassia and Wilke [1991]).

Runs on other institutions accelerated after the closing of Heritage on November 16. The Rhode Island Central Credit Union was particularly hard hit during December 1990, apparently borrowing $\$ 20$ million from the Rhode Island Credit Union League-Corporate Central Union (RICUL-CCU) to fund the runs. During the weekend of December 29-30, RICUL-CCU essentially took over Rhode Island Central's premises and assets to secure its loans. On December 31, apparently urged to do so by the National Credit Union Administration (NCUA), RICUL-CCU refused to extend any more credit to Rhode Island Central to cover the checks it was issuing for withdrawals. NCUA officials argued correctly that further loans to Rhode Island Central from RICUL-CCU, which had both federally insured and RISDIC-insured members, might mean that deposits of the federally insured 
members were being used to fund runs on RISDIC-insured members, especially Rhode Island Central. Also, on December 31, 1990, RISDIC's board met, decided against a second assessment of members, and asked that a conservator be appointed to take over RISDIC's affairs (Gregorian [1991]).

\section{Common Factors in the Downfall of the Three State Funds}

The private deposit insurance funds in Ohio, Maryland, and Rhode Island had some common characteristics that led in various degrees to their ultimate collapses. All were dominated by the regulated industry (state-chartered S\&Ls in Ohio and Maryland and credit unions in Rhode Island), and all seemed to have considerable influence in their state legislatures regarding the expansion of their lending and investment powers (as distinguished from the lesser restraining influence of the relevant state supervisory and regulatory bodies).

The problems of the largest insured institutions were identified in supervisory examinations or outside audits years before the final collapses of the insurance funds in each state. However, for a variety of reasons -- summarized in one account as a lack of necessary supervisory "clout" -- ineffective corrective actions or, as in Ohio, virtually no corrective actions at all were taken. ${ }^{6}$

The state political authorities in each case initially attempted to deny the magnitude of the insurance fund's problem once the insolvencies of the insured institutions posing the largest risks to the fund were revealed. They used devices like 1) the self-evidently deficient capitalization of the successor fund in Ohio (Kane [1992]), 2) the appointment of conservators instead of receivers in all three states once the largest insolvent insured institutions and the 
funds themselves were shown to be profoundly insolvent and not merely temporarily illiquid (see Todd and O'Driscoll [1993]), and 3) strategies based on the groundless assumption that the FSLIC (Ohio and Maryland) or the National Credit Union Administration (Rhode Island) would take the worst cases off their hands without substantial injections of state funds. ${ }^{7}$

The primary common element among the collapses of the three funds was their incapacity to exercise sufficient supervisory authority to limit risks or to impose effective riskbased deposit insurance premiums to make unwise risk-taking more costly for the insured institutions creating the largest risks. In the absence of effective restraints on risk-taking, and without adequate insurance reserves or assurance of replenishment following recognition of loss, any large loss was bound to undermine public confidence and to trigger rational runs by depositors on other institutions insured by the same fund if the solvency of those other institutions was also questionable. In each of the three states, the political authorities waited until runs had spread to several other institutions insured by the same fund before closing all the privately insured firms or imposing limitations on withdrawals. ${ }^{8}$

\section{RISDIC's Collapse Distinguished from Those in Ohio and Maryland}

Some factors, however, clearly separate the collapse of RISDIC from the Ohio and Maryland failures. The principal economic factor behind the failure of RISDIC-insured institutions was real estate loan and investment losses in New England, which were particularly severe between 1989 and 1992 (Randall [1993]; Syron [1991]), while the failures of the privately insured institutions in Ohio and Maryland causing the largest losses were attributable to imprudent involvement with fraudulent government securities dealers. ${ }^{9}$ Real estate loan and 
investment losses were significant in the Maryland crisis and in Ohio for institutions other than Home State, the largest failed S\&L.

While geographic concentration of lending and investment risks generally exacerbates the tendency of depository institutions to fail during regional economic downturns, the extreme degree of geographic concentration in Rhode Island, combined with the particular nature of the primary loan and investment risk of the RISDIC-insured institutions (real estate), made the proportional loss from book value during the regional downturn much greater, on a fundwide basis, than actually occurred in Ohio and Maryland (Syron [1991]). Fund losses did not exceed 10 percent of insured deposits in Ohio and Maryland, but in Rhode Island, that share approached one-third. Also, while the state-chartered S\&Ls and building and loan associations in Ohio and Maryland had many economic characteristics in common with the state-chartered credit unions and industrial banks in Rhode Island, the legal and institutional structures of credit unions and industrial banks are so different from the structures of traditional housing lenders as to warrant a somewhat different analysis. ${ }^{10}$

The greatest dissimilarities between the Rhode Island crisis and those in the other two states were in the solutions that state authorities actually achieved: There was a congressional field hearing in Warwick, Rhode Island, in May 1991, five months after the RISDIC-insured institutions were closed and while state authorities were still trying to develop a funding vehicle for frozen claims. Neither Ohio nor Maryland achieved such a field hearing, but there was a congressional hearing on the Ohio crisis in Washington, D.C. about one month afterward, which also was about one month before the governor declared an emergency in Maryland (U.S. House of Representatives [1985]; ibid. [1991]). Also, while both Ohio and 
Maryland officials requested federal financial assistance to resolve their deposit insurance fund problems, only Rhode Island received such direct assistance (a federal loan guarantee), almost certainly a result of the congressional field hearing. ${ }^{11}$

In each of the three states, the private deposit insurance fund had become fairly large before the final crisis struck: Ohio had $\$ 4.2$ billion of insured deposits in 70 institutions, with $\$ 130$ million available to the insurance fund; Maryland had $\$ 7.2$ billion of insured deposits in 102 institutions, with $\$ 175$ million available to the insurance fund; and Rhode Island had $\$ 1.8$ billion of insured deposits in 46 institutions as of September 30, 1990, the last calendar quarter before Governor Sundlun closed the 45 remaining institutions, with $\$ 25$ million available to the insurance fund (Federal Reserve Bank of Cleveland [1985]; Gregorian [1991]). In Rhode Island, the comparative importance of the RISDIC problem was somewhat more pronounced than in the other two states because RISDIC insured 357,000 individual accounts, about one for every three persons in Rhode Island. ${ }^{12}$

Some notable differences emerged in the failure resolution techniques used by state and some federal officials in the three states studied. In Ohio, the governor proclaimed an emergency bank holiday that required all institutions insured by the failed private fund to close until they were either assured of receiving federal deposit insurance or sold or merged into a federally insured institution. The remaining institutions, except for Home State, the largest and most profoundly insolvent firm, were allowed to reopen under the supervision of the state's Division of Savings and Loans on a limited-withdrawals basis, in most cases not more than $\$ 750$ per account per month (later increased to $\$ 1,000$ ). While all depositors of institutions insured by the failed fund were denied access to their funds during the emergency 
holiday period (March 15-21, 1985), the combination of full and partial reopenings on and after March 21 enabled depositors at 59 of the 68 remaining firms to gain at least partial access to their money by March 25. Because the Ohio institutions held a fairly high proportion of assets of good quality, the liquidity problems of all but a few were minimal: The peak amount of Federal Reserve Bank of Cleveland discount window advances to those institutions was only $\$ 45$ million during the reserves maintenance week ending March 27, 1985, less than 2 percent of all non-Home State deposits insured by the private fund. The State of Ohio committed $\$ 151$ million of nontax revenues (e.g., liquor monopoly and lottery surpluses) to support bonds issued to fund the reopenings, and full access to deposits was restored at all but one small institution ( $\$ 59$ million of deposits) by January 3, 1986. Depositors of all but three institutions received full availability of funds within six months after the March closings (Federal Reserve Bank of Cleveland [1985]).

In Maryland, queues of depositors seeking to withdraw their money from Old Court Savings and Loan, the largest severely impacted privately insured institution (nearly $\$ 1$ billion of total assets), were shown on television newscasts on May 9, 1985, and such visible runs then spread to other privately insured institutions, especially Merritt Commercial Savings and Loan Association. The $\$ 200$ million estimated loss at Old Court alone exceeded the $\$ 175$ million available in the Maryland private insurance fund. By May 13, conservators were appointed for both Old Court and Merritt, and on May 14, Governor Hughes proclaimed a state of emergency that limited withdrawals from all privately insured S\&Ls to $\$ 1,000$ per account per month. Federal Reserve Bank of Richmond advances to the Maryland institutions were much larger and of longer duration than in Ohio. The Maryland institutions had 
borrowed $\$ 375$ million by May 14,1985 , and Old Court alone had already borrowed $\$ 75$ million by April 18. Maryland advances lingered on the books of the Federal Reserve Bank of Richmond: The last borrowings were not repaid until 1989. Several large institutions, including Old Court, Merritt, and Community Savings and Loan, had all their deposits frozen for several months. By January 1986 , more than $\$ 1.15$ billion of Maryland deposits were still frozen, not even available for partial withdrawals.

The eventual solution involved a combination of state-sponsored bond issues and a continuation of withdrawal limitations at Old Court and Community to provide a full return of principal over five years: Some Maryland depositors were not repaid in full until 1989. However, apparently at the urging of senior Federal Reserve officials, state authorities decided to avoid a complete closing of all privately insured institutions, totally froze the claims of depositors at only three institutions, committed sufficient state-sponsored bond revenues to cover all insured deposits over five years, and avoided "haircuts," or partial final payouts to depositors (Preston [1986]; Federal Reserve Bank of Cleveland [1985]). The Maryland solution differed substantially from the Ohio and Rhode Island solutions because of the protraction in the full return of insured deposits, the far greater reliance on and continuation of Federal Reserve liquidity assistance, and the avoidance of a complete closing of all privately insured institutions.

In Rhode Island, depositors obtained the full return of their principal far less quickly than in Ohio but far more quickly than in Maryland, and there was no actual use of Federal Reserve liquidity assistance. However, Rhode Island obtained and made use of a federal loan guarantee for its state-sponsored bond issues aimed at resolving the crisis, which did not occur 
in the other two states. As in Ohio, Rhode Island authorities ordered all privately insured institutions completely closed, which had the effect of freezing all deposits until the affected firms were sold, merged, or liquidated. Fortunately, from the depositors' viewpoint, there were no involuntary haircuts or discounted returns of their deposit principal. Unfortunately, from the taxpayers' viewpoint, the depositors' potential losses in Rhode Island were distributed over a pool of taxpayer households that was roughly identical to the pool of depositor households. In Ohio and Maryland, depositors' losses could be distributed over larger population sets because depositor households represented a minority of taxpayer households. Therefore, it was unlikely that Rhode Island's chosen solution was politically feasible without the federal government bearing the residual risk of loss via the $\$ 180$ million federal loan guarantee for the 1991 series A DEPCO bond issue.

\section{Conclusion}

It took nearly three years after the closing of the RISDIC-insured institutions for depositors at six of them to be able to obtain the full return of their principal. Rhode Island succeeded in obtaining a federal loan guarantee for the rescue effort where Ohio and Maryland failed, but even the $\$ 180$ million of federally guaranteed bonds filled only about one-third of the hole in RISDIC's net worth that federal authorities expected when the liquidations began in 1991 (U.S. House of Representatives [1991]). And it appears that a remaining gap of about $\$ 356$ million still has to be filled. The principal comparatively painless means of closing that gap are receipts from liquidations, revenues from performing loans in DEPCO's asset portfolio, and the anticipated proceeds of litigation against RISDIC's auditors and some 
officers and directors of RISDIC-insured institutions. However, the only consistently reliable funds available to DEPCO are the dedicated portion of a special state sales tax currently generating about $\$ 38$ million per year, of which about one-half must be set aside for debt service on outstanding bonds. All of these amounts are quite large for a state economy the size of Rhode Island's.

Prompt liquidation and sale of insolvent RISDIC-insured institutions with no guarantee of full recovery to depositors, even allowing for the federal loan guarantee of $\$ 180$ million, would have saved Rhode Island taxpayers as much as $\$ 356$ million at present value (the remaining unfunded DEPCO deficit) and still would have enabled DEPCO to distribute about 70 cents per dollar of insured deposits to depositors. This alternative would have been politically difficult, to be sure, because the collapse of RISDIC in early January 1991 coincided with the failure of the Bank of New England and initially affected nearly every household in Rhode Island. The involvement of prominent Rhode Island politicians in RISDIC's affairs prior to its collapse also made it difficult for those politicians to appear to walk away from the crisis. Also, contagious bank runs apparently did occur: The Federal Reserve Bank of Boston reported that it made 30 emergency shipments of currency to Rhode Island and southeastern Massachusetts in January 1991 alone (Syron [1991]). It turned out that the records and accounting systems of several of the largest failed RISDIC-insured institutions were so poor that it required several months to determine the expected loss for each and that a prompt liquidation and sale would have been nearly impossible. Thus, although deposits of those institutions would have remained frozen for several months -- they remained frozen for several months anyway under the solution actually pursued. Nevertheless, if sales tax 
collections devoted to DEPCO can be maintained at current levels, and if the Rhode Island legislature continues to vote to devote those revenues to DEPCO, there is no reason why the current solution cannot succeed in extinguishing the remaining deficit over a long period, which would tend to validate the political authorities' choice of that solution.

The virtual disappearance of state-chartered private deposit insurance funds tends to support some general inferences regarding private deposit insurance, cross-guarantee arrangements, private clearinghouses, and the like, but also provides far less support than might be imagined for other general inferences. Foremost among those supported is that great care must be taken in any private deposit insurance fund or analogous arrangement to prevent the largest institutions from exercising undue influence over examinations, accounting matters, premium adjustments for risk, and the timing and basis of appointment of receivers and conservators. Steps to ensure the independence of a majority of the insurance fund's directors would help to prevent such undue influence. But it probably is too strong an inference to conclude from the Ohio, Maryland, and Rhode Island examples that private deposit insurance cannot work anywhere: It can and should work properly if the structural independence of the governing board of the insurance fund deprives the most politically influential institutions of the fruits of their influence in the matters mentioned above.

However, as in Rhode Island, the existence of any kind of federal safety net (in that case, a federal loan guarantee; in cross-guarantee plans, the availability of federal deposit insurance as a backup) tends to create a moral hazard problem for state and private insurance fund officials: Why should they become more effective in assessing and responding to increased risk in their insured institutions if they know that a federal rescue of some sort is 
achievable? In that respect, even the Federal Deposit Insurance Corporation (FDIC) can be no more effective over time than the structural independence of its governing board would allow: If the FDIC itself were subject to political pressure from either its largest insured institutions or government officials, then there is little reason to expect its performance over time to exceed that of Ohio, Maryland, and Rhode Island officials (see especially Kane [1992]).

The resolution methods studied in these three states show that some methods are superior to others for specific purposes, but each state also experienced shortcomings in the resolution methods actually chosen. In Ohio, the emergency closing of all privately insured S\&Ls forced state officials to deal with the crisis in a more comprehensive way and more rapidly than would likely have been the case if a regime of partial withdrawals had been pursued from the beginning. Further, the Ohio solution was the cheapest of the three in terms of the expenditure of state-controlled funds, and it caused a more rapid return to full availability of principal for nearly all depositors, with no direct federal assistance.

In Maryland, the emergency restriction on withdrawals, combined with comparatively large Reserve Bank discount window support for liquidity advances, tended to stop the runs on both solvent and insolvent institutions and temporarily relieved state political officials of some of the sentiment of urgency that was present in Ohio. However, those measures also burdened Maryland taxpayers with indirect responsibility for the eventual repayment of the Federal Reserve advances -- advances that, coming from a federal instrumentality, created the legal hurdle of a first lien that any state-crafted financial solution would have to overcome.

In Rhode Island, the emergency closing of all RISDIC-insured institutions stopped the runs, but may have inadvertently created long delays for depositors in obtaining full access to 
their deposit principal. About two-thirds of all depositors' claims were still frozen for the greater part of 1991, and doubts generated regarding the soundness of Rhode Island's statesupervised institutions contributed to a second series of runs in late January 1991 that weakened and forced the subsequent closing of a much larger institution, Old Stone Bank of Providence ( $\$ 1.9$ billion of total assets), a state-chartered savings bank insured by the FDIC. ${ }^{13}$ Apart from Old Stone, the percentage of losses in Rhode Island was so large (approaching onethird of RISDIC-insured deposits) that a state-only solution appeared politically impractical, but with the defeasance last year of remaining DEPCO obligations for the federally guaranteed bonds, the state has in fact achieved an entirely state-funded solution.

Finally, the Rhode Island experience does not suggest that state-supervised credit unions are more vulnerable to bad management, loan losses, poor investment decisions, or depositor runs than are other types of mutual savings associations. With the exception of the largest RISDIC-insured credit unions, the percentage of losses in Rhode Island was greatest at institutions that were not even credit unions--they were loan and investment banks or industrial banks.

The real problem that any state supervisory authority or any private deposit insurance fund's supervisory board must confront is its capacity to supervise the largest depository institutions effectively and to retain sufficient political independence to be able to take strict enforcement actions against their imprudent banking practices. If a sufficient degree of supervisory capacity and political independence cannot be obtained, then it probably would be a good idea for such states to tender supervision of the relevant classes of depository institutions to the federal authorities and to stop chartering private deposit insurance funds. 
Some states, such as Massachusetts and North Carolina, apparently had the capacity to supervise privately insured institutions effectively but nevertheless withdrew from such supervision as a general practice. Other states, such as Ohio, Maryland, and Rhode Island, clearly lacked the capacity to supervise privately insured depository institutions adequately and probably should have been discouraged from issuing new charters for such institutions.

In general, the case for the preservation of the dual banking system, with depository institution charters issued and supervision conducted by state as well as federal authorities, is weakened only superficially by the examples selected from Ohio, Maryland, and Rhode Island. Once one understands the true nature of those deposit insurance crises, one sees that, at the relevant times, the federal deposit insurance system shared many of the same weaknesses (subsequently remedied somewhat by enactment of the Federal Deposit Insurance Corporation Improvement Act of 1991) with the deposit insurance funds in those states. If new banking powers initiated under state law, such as the underwriting and retail brokerage of life insurance or annuity contracts, become widespread, the story told here will not require federal supervision of those powers. However, this story does indicate that states will have to monitor the exercise of those powers carefully if future federal supervision and further erosion of the dual banking system are to be avoided. 


\section{Appendix: Sources and Uses of Funds for RISDIC's Liquidation}

1. RISDIC-insured institutions by charter type at closing:

Credit unions $\quad 35$

Loan and investment companies $\quad 7$

Bank and trust companies $\quad \underline{3}$

Total 45

2. Resolutions:

Institutions reopened with NCUA insurance 25

Loan and investment companies becoming inactive

Institutions liquidated in 1991

Institutions acquired by other federally insured institutions during 1991-92 6

Institutions that are still self-liquidating under court supervision 1

Cases remaining with DEPCO-funded liquidation $\quad \underline{5}$ Total

3. DEPCO financial statements as of $6 / 30 / 93$ :
Liabilities
\$ 698.8 million
Assets 395.9 million
Remaining fund deficit
$\$ 302.9$ million

4. Principal sources of DEPCO funds (amounts outstanding as of 6/30/93):

DEPCO bonds payable from specifically assigned funds:

Series A (1991)

Series A (1992)

Series B (1992)

Total Series A \& B
\$ 31.6 million 304.8 million 133.4 million $\$ 469.8$ million

DEPCO bonds payable from its general funds:

Series A (senior secured)

Series B (subordinated \& unsecured)

$\$ 52.8$ million Total general obligation bonds 55.9 million $\$ 108.7$ million

Gross total of all bonds outstanding Reserves and sinking funds for bond $\$ 578.5$ million issues (restricted assets)

(\$102.6 million) 
5. DEPCO liabilities for funding of frozen RISDIC-insured deposits as of 6/30/93:

Guaranteed deposit liabilities

Due to receiverships for deposits

Total remaining guaranteed deposits

$\$ 57.7$ million

10.3 million

$\$ 68.0$ million

6. Total DEPCO primary liabilities (bonds plus deposit guarantees):

Total of items 4 and 5

$\$ 646.5$ million

7. Total DEPCO liquidity reserves in the form of cash or cash equivalents as of 6/30/93:

Cash and cash equivalents available for reserves against deposits

Restricted assets (see item 4)

$\$ 19.6$ million

$\underline{102.6 \text { million }}$

Total

$\$ 122.2$ million

8. Total of DEPCO primary liabilities less primary cash reserves:

Item 6 less item 7

$\$ 524.3$ million

9. Liquidating assets available to finance bond, deposit guarantee, and other liabilities as of 6/30/93:

At book value (net of valuation reserves)

Of which loans and real estate owned (net of valuation reserves of at least $\$ 169.9$ million)

$\$ 254.2$ million

And of which due from receiverships and said to

$\$ 203.9$ million include environmentally tainted properties

Cash

Loans

Real estate owned

Other assets

Total

$\$ \quad 6.2$ million

31.1 million 11.0 million

0.6 million

$\$ 48.9$ million 
10. Proposed valuation adjustments for:

Environmentally tainted receivership assets at a $30 \%$ discount from current book value (loans plus real estate owned, from item 9)

Liquidation value of loans and real estate owned by DEPCO at $20 \%$ discount from current book value (from item 9)

Total proposed adjustments

(\$53.4 million)

11. Restatements of DEPCO fund deficit as of 6/30/93:

DEPCO's statement, at book value

$\$ 302.9$ million

Pulkkinen and Rosengren estimate (January 1993)

$\$ 389.0$ million

DEPCO's statement, adjusted for item 10

$\$ 356.3$ million

NOTE: Special state sales tax proceeds devoted to DEPCO bond service yielded fiscal year 1993 collections of $\$ 38.1$ million, and $\$ 31.9$ million was spent during that fiscal year for bond defeasance, primarily the defeasance of the federally guaranteed bond issue.

SOURCES: DEPCO (1993) and Pulkkinen and Rosengren (1993). 


\section{FOOTNOTES}

1. See generally Federal Reserve Bank of Cleveland (1985), Preston (1986), Gregorian (1991), and Todd (1994). Credit unions and, prior to 1980, S\&Ls typically offered share accounts, a legal concept analogous to but distinct from deposit accounts. In an uninsured mutual savings association, the holders of share accounts are, literally, the owners of the association and share in its profits and losses to the extent that they exceed regulatory networth minimums.

2. See Kane $(1985 ; 1989 ; 1992)$ for background materials on the collapse of thrift industry deposit insurance funds in the 1980s. The role of improper accounting methodology in enabling the industry's problems to intensify is addressed specifically in Thomson (1992).

3. One of the principal problems with the institutional structure of RISDIC identified in the 1991 investigative report to Rhode Island Governor Bruce Sundlun was a high concentration of insured deposits in large undercapitalized credit unions. For example, the three largest institutions held about 45 percent of all RISDIC-insured deposits (about $\$ 800$ million of the $\$ 1.8$ billion total as of September 30, 1990) (Gregorian [1991]). See also Syron (1991).

4. It appears that the particular treatment of contingent losses reported by RISDIC's outside auditor, 1982-88, was permissible under Generally Accepted Accounting Principles at those times and enabled the auditor to give unqualified or clean opinions, but the auditor had to believe that it was unlikely any large member of RISDIC would fail to justify that opinion. See Gregorian (1991). Rhode Island authorities have sued the auditor, but the matter is still unresolved (McCarthy [1994]).

5. In fairness to those officials, it must be said that they may have been unaware of the probable consequences of their legislative actions for the Rhode Island credit union industry and that they may have intended no harm. However, in early 1986, Federal Reserve Bank of Boston officials gave explicit warnings to the then-governor and his staff regarding the likely outcome of failure to require federal insurance for all RISDIC members (Syron [1991]).

6. See Pulkkinen and Rosengren (1993). 
7. See generally U.S. House of Representatives (1985), Federal Reserve Bank of Cleveland (1985), Preston (1986), Gregorian (1991), and Syron (1991).

8. Authorities are divided as to whether "rational" bank runs (i.e., those based on accurate information or reasonable suspicion) should be tolerated or even encouraged in order to force politicians and regulators to take necessary corrective actions (see Kane [1992] and Kaufman [1988]) or, rather, should be discouraged lest such runs communicate "systemic risk" to other, sound institutions (see, for example, Syron [1994]). All authorities are in general agreement that "irrational" bank runs (i.e., those based on inaccurate information regarding the solvency of particular institutions or insurance funds) should be resisted.

9. See U.S. House of Representatives (1985) and Preston (1986) regarding Ohio and Maryland. Large insured institutions in these states engaged in collateralized reverse repurchase transactions covering U.S. government securities with securities dealers that required excess collateral from the S\&Ls that were borrowing funds. Meanwhile, the securities dealers' collateral custody arrangements were deficient: They used custody receipts for the same collateral to cover multiple pledges. Safe collateral procedures are distinguished from those used in the Ohio and Maryland cases in Stevens (1987).

10. See Kane and Hendershott (1992) and Moysich (1990) for important and useful studies of the risk characteristics that distinguish credit unions from other types of depository institutions.

11. See Federal Deposit Insurance Corporation Improvement Act of 1991, section 431. In the May 24, 1991 field hearing of the House Banking, Finance, and Urban Affairs Committee, Rhode Island Governor Sundlun noted that the state's congressional delegation had two requests before Congress for a $\$ 150$ million outright grant and a $\$ 150$ million low-interest loan to DEPCO. Governor Sundlun made a third proposal, the one actually enacted, to have Congress provide a federal loan guarantee for a DEPCO bond issue in an amount between $\$ 150$ million and $\$ 210$ million. The amount approved was $\$ 180$ million (U.S. House of Representatives [1991]). 
12. The average (arithmetic mean) RISDIC-insured account was less than $\$ 6,000$, but the mean is skewed upward by the comparatively small number of high-dollar-value accounts. The median account value probably was somewhat less than $\$ 6,000$.

13. Old Stone was gravely weakened by the January 1991 runs, losing $\$ 130$ million during 1991 and \$29 million during the first nine months of 1992 . The bank unsuccessfully sought a purchaser or better-capitalized merger partner for most of 1991 and 1992. When its tangible net worth ratio declined to 1.2 percent by January 1993 , Old Stone was placed into receivership. Its depositors were not delayed in gaining access to their funds at that time because their accounts were covered by federal deposit insurance. In July 1994, Royal Bank of Scotland purchased Old Stone from the Resolution Trust Corporation through its principal U.S. subsidiary, the Citizens Financial Group of Providence, Rhode Island. Royal paid a premium of $\$ 134$ million and received $\$ 1.1$ billion of deposits and \$450 million of selected loans (Smith [1994]; Vogelstein [1993]). 


\section{REFERENCES}

DEPCO. Excerpts from "Statement of Assets, Liabilities, and Fund Deficit" and "Statement of Cash Flows." Providence, R.I.: Rhode Island Depositors Economic Protection Corporation, June 30, 1993.

Federal Reserve Bank of Cleveland. "Unfoldings in Ohio," Annual Report 1985.

Flood, Mark D. "The Great Insurance Debate," Federal Reserve Bank of St. Louis, Review, vol. 74, no. 4 (July/August 1992), pp. 51-77.

Gregorian, Vartan. "Carved in Sand: A Report on the Collapse of the Rhode Island Share and Deposit Indemnity Corporation," prepared for the governor of Rhode Island, March 14, 1991.

Ingrassia, Lawrence, and John R. Wilke. "Road to Trouble: How Lax Regulation Threw Rhode Island into Banking Turmoil," Wall Street Journal, March 6, 1991.

Kane, Edward J. The Gathering Crisis in Federal Deposit Insurance. Cambridge, Mass.: MIT Press, 1985.

- The S\&L Insurance Mess: How Did It Happen? Washington, D.C.: Urban Institute Press, 1989.

. How Incentive-Incompatible Deposit Insurance Funds Fail," in George G. Kaufman, ed., Research in Financial Services: Private and Public Policy, vol. 4. Greenwich, Conn.: JAI Press, Inc., 1992.

, and Robert J. Hendershott. "Privatizing Proactive Loss-Control Decisions: Lessons from the Credit Union Movement," Ohio State University, Department of Finance, unpublished paper, 1991.

Kaufman, George G. "The Truth about Bank Runs," in Catherine England and Thomas Huertas, eds., The Financial Services Revolution: Policy Directions for the Future. Boston: Kluwer Academic Publishers, 1988, pp. 9-40.

McCarthy, Jack. Conversations with the author regarding DEPCO, 1994.

Moysich, Alane K. "An Overview of the U.S. Credit Union Industry," FDIC Banking Review, vol. 3, no. 1 (1990), pp. 12-26.

Preston, Wilbur D., Jr. "Report of the Special Counsel on the Savings and Loan Crisis," prepared for the governor of Maryland, January 8, 1986. 
Pulkkinen, Thomas E., and Eric S. Rosengren. "Lessons from the Rhode Island Banking Crisis," Federal Reserve Bank of Boston, New England Economic Review, May/June 1993, pp. 3-12.

Randall, Richard E. "Lessons from New England Bank Failures," Federal Reserve Bank of Boston, New England Economic Review, May/June 1993, pp. 13-38.

Smith, Alison. “Royal Bank Completes U.S. Buy," Financial Times, July 11, 1994, p. 18.

Stevens, E.J. "Seeking Safety," Federal Reserve Bank of Cleveland, Economic Commentary, April 15, 1987.

Syron, Richard F. "Statement by Richard Syron, President, Federal Reserve Bank of Boston, before the Subcommittee on General Oversight and Investigations of the Committee on Banking, Finance, and Lrban Affairs, U.S. House of Representatives, April 17," Federal Reserve Bulletin, vol. 77, no. 6, 1991, pp. 425-30.

- "The Fed Must Continue to Supervise Banks," Federal Reserve Bank of Boston, New England Economic Review, January/February 1994, pp. 3-8.

Thomson, James B. "A Market-Based Approach to Reforming Bank Regulation and Federal Deposit Insurance," in George G. Kaufman, ed., Research in Financial Services: Private and Public Policy, vol. 4. Greenwich, Conn.: JAI Press, Inc., 1992, pp. 93-109.

Todd, Walker F. "Lessons from the Collapse of Three State-Chartered Private Deposit Insurance Funds," Federal Reserve Bank of Cleveland, Economic Commentary, May 1, 1994.

, and Gerald P. O'Driscoll, Jr. "Deposit Insurance Reform Is Not Enough," in Lawrence H. White, ed., The Crisis in American Banking. New York: New York University Press, 1993, pp. 119-38.

U.S. House of Representatives, Subcommittee of the Committee on Government Operations. "Ohio Savings and Loan Crisis and Collapse of ESM Government Securities, Inc." Hearing, 96 Cong. 1 Sess., April 3, 1985.

U.S. House of Representatives, Committee on Banking, Finance, and Urban Affairs. "Rhode Island Banking Crisis." Field hearings, 102 Cong. 1 Sess., May 24-25, 1991. 
clevelandfed.org/research/workpaper/index.cfm

Vogelstein, Fred. "Banks Mull Old Stone Bid," American Banker, February 2, 1993, p. 14.

Wheelock, David C., and Paul W. Wilson. "Can Deposit Insurance Increase the Risk of Bank Failure? Some Historical Evidence," Federal Reserve Bank of St. Louis, Review, vol. 76, no. 3 (May/June 1994), pp. 57-71. 